\title{
Comparison of Nitrogen Removal Efficiencies and Microbial Communities of Full-Scale Anaerobic, Anoxic and Aerobic Processes in Municipal Wastewater Treatment Plants having Low and High COD/TN Ratios
}

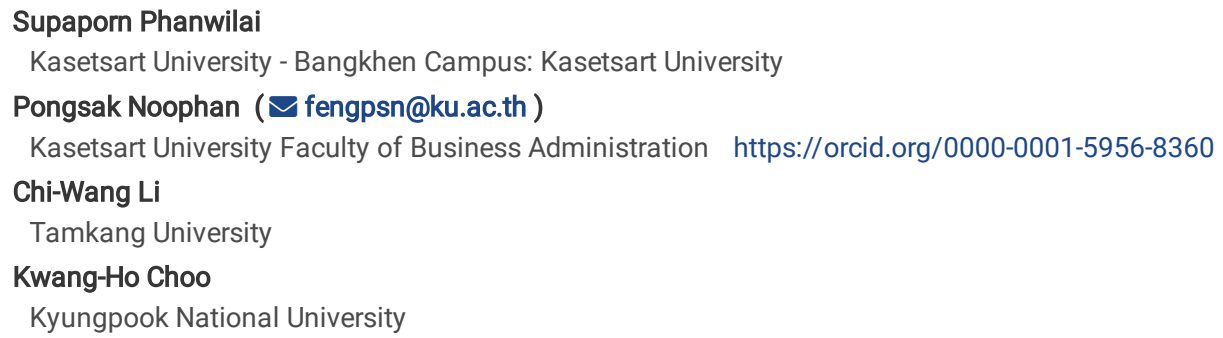




\section{Abstract}

Full-scale anaerobic, anoxic and aerobic $\left(\mathrm{A}^{2} \mathrm{O}\right)$ process is used worldwide for biological nutrient removal (BNR). However, operation parameters for nitrogen removals and information of microbial communities related to nitrogen removal in full-scale $\mathrm{A}^{2} \mathrm{O}$ wastewater treatment plants (WWTPs) having low and high COD/TN ratios are not available. Based on the analysis of four full-scale $A^{2} O$ WWTPs, it is suggested that maintaining longer SRT of $\geq 30$ day and DO of $\geq$

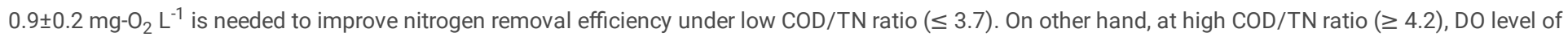
$\geq 2.6 \mathrm{mg}-\mathrm{O}_{2} / \mathrm{L}$ and typical SRT of $19-25$ days would be suggested. It was confirmed that phosphorus removal efficiency significantly improved under BOD/TP ratio of $>20$ for $\mathrm{A}^{2} \mathrm{O}$ process in these full-scale WWTP.

Microbial distribution analysis showed that ammonia-oxidizing archaea (AOA) was abundant under conditions of low DO level, longer SRT, high temperature and low COD/TN ratio ( $\leq 3.7)$. Nitrosomonas sp. are mostly found in aerobic tank of full-scale $\mathrm{A}^{2} \mathrm{O}$ WWTPs. However, abundances of Nitrosomonas sp. are proportional to DO and $\mathrm{NH}_{4}{ }^{+}$concentrations for WWTPs with high COD/TN ratio. Nitrosospira sp. are only found under operating condition of longer SRT for WWTPs with low COD/TN ratio. Abundances of Nitrobacter sp. are proportional to DO concentration and temperature rather than abundance of Nitrospira sp. Predominance of nosZ-type denitrifiers were found at low COD/TN ratio. Abundance of denitrifiers by using nirS genes was over abundance of denitrifiers by using nirK genes at high COD/TN ratios WWTPs.

\section{Introduction}

Organic matters and inorganic nutrients are the main contaminants to be treated in municipal wastewaters. Discharge of inorganic nutrients such as nitrogen $(\mathrm{N})$ and phosphorus $(\mathrm{P})$ compounds with to environment is responsible for eutrophication or algal blooms and toxic effects to aquatic life. For this reason, organic matter and inorganic nutrients have to be removed before discharging wastewaters to environment. Biological treatment processes are often recommended because of high removal efficiency and inexpensive operation cost compared to physical and chemical treatment processes. Modified LudzackEttinger (MLE) consisting of anoxic and aerobic processes is specifically designed for $\mathrm{N}$ removal. $\mathrm{A}^{2} \mathrm{O}$ consists of anaerobic, anoxic and aerobic processes and is used worldwide to remove both $\mathrm{N}$ and $\mathrm{P}$ biologically in which abundance of microorganisms responsible for various nutrient removal is achieved under designed environmental conditions. With alkalinity provided for nitrification step, $\mathrm{A}^{2} \mathrm{O}$ processes can remove both nitrogen and phosphorus efficiently, producing good settling sludge. The energy cost is low and operation is relatively simple. Internal nitrate recycle through proper control of recycling return activated sludge (RAS) from aerobic zone to the anoxic zone is the key to operate $A^{2} O$ process successfully [1]. When designing $A^{2} O$ processes, wastewater characteristics and operation parameters including contact time of anaerobic tank, solids retention time (SRT), hydraulic retention time (HRT), DO concentration, etc. must be taken into consideration. Wastewater with proper carbon and total nitrogen ratio, i.e., COD/TN ratio, results in good process performance. Typical COD/TN ratio of $\geq 4$ for denitrification process (anoxic tank) and BOD/TP ratio of 20 for biological phosphorus removal process (anaerobic tank) are observed for an $\mathrm{A}^{2} \mathrm{O}$ processes with excellent $\mathrm{N}$ and $\mathrm{P}$ removal [1]. Insufficient carbon source for denitrification process occurs in municipal wastewater with low COD/TN ratio, resulting in low N removal performance [2]. External carbon source addition [3] or maintaining longer SRT [4] are the most effective approaches to improve biological $\mathrm{N}$ removal performance for wastewater with low COD/TN ratio. Investigating the effects of SRT on $\mathrm{N}$ removal efficiency, Liu et al. [5] reported that system with SRT at 40 day outperformed those with shorter SRTs (5, 10, and 20 day). Phanwilai et al. [4] achieve excellent $\mathrm{N}$ removal with a step feed treatment process operated at SRT of 60 day. Biological $\mathrm{N}$ removal can be improved by optimizing DO levels. In case of keeping very low DO level of $0-0.5 \mathrm{mg}-\mathrm{O}_{2} \mathrm{~L}^{-1}$, ammonia-oxidizing archaea (AOA) would be the dominant microorganisms group responsible for $\mathrm{N}$ removal [6]. Increasing abundance of ammonia-oxidizing bacteria (AOB) was reported with a high DO level of $1.9-3.5 \mathrm{mg}^{-} \mathrm{O}_{2} \mathrm{~L}^{-1}[6]$. The domination of Nitrospira was observed at DO below $1.0 \mathrm{mg}-\mathrm{O}_{2} \mathrm{~L}^{-1}[7]$.

Temperature and free ammonia (FA) are also important factors affecting the microbial community. Temperature at $10-20^{\circ} \mathrm{C}$ was reported to be the optimum range for Nitrospira [8] and the temperature at $24-25^{\circ} \mathrm{C}$ is favorable for Nitrobacter [7]. FA was an inhibitor of NOB activity [9]. Furthermore, Nitrobacter is more sensitive to FA than Nitrospira [10].

This research work focused on the nitrogen removal performance, identification and quantification of microbes from anaerobic, anoxic, and aerobic tanks of $\mathrm{A}^{2} \mathrm{O}$ processes in four full-scale municipal WWTPs having low $(\leq 3.7)$ to high $(\geq 4.2)$ COD/TN ratios. In this work, only nitrogen removal efficiencies were compared and discussed by using results from microbial quantity and communities of bacteria related to nitrogen removal, such as $A O A$, AOB, nitrite-oxidizing bacteria (NOB), and denitrifying bacteria (DNB) in these four full-scale $\mathrm{A}^{2} \mathrm{O}$ WWTPs. In addition, the results from this work could be applied to increase $\mathrm{N}$ removal efficiencies of these four full-scale WWTPs.

\section{Materials And Methods Description of the study sites}

$\mathrm{A}^{2} \mathrm{O}$ processes from four full-scale WWTPs with wide ranges of COD/TN ratios were selected as the study sites. Two WWTPs were located in Ding Daeng, Bangkok and Samut Prakan Province, Thailand, and are denoted as WWTP TH1 and TH2, respectively. The other two full-scale WWTPs, Dalseocheon and Sincheon WWTPS, were located in Daegu, South Korea, and are denoted as WWTP SK1 and SK2, respectively. $A^{2} O$ processes in these full-scale WWTPs were mainly designed for BNR, especially for biological both nitrogen and phosphorus removals. The influent COD/TN mass ratios at TH1, TH2, SK1, and SK2 were $3.7,8.4,4.2$, and 5.6, respectively. TH1 is considered to have low COD/TN ratio ( $\leq 3.7)$, while TH2 has relatively high COD/TN ratio (>4) due to the wastewater being mainly generated from aircrafts, business and commercial buildings, such as hotels and airlines' offices, in the surrounding of Suvarnabhumi airport. 
The schematic layout of the full-scale $\mathrm{A}^{2} \mathrm{O}$ processes in the $\mathrm{TH} 1$ and $\mathrm{TH} 2$ is shown in Fig. 1 (A). The schematic layout of full-scale $\mathrm{A}^{2} \mathrm{O}$ processes in the SK1 and SK2 (with 1st and 2nd clarifiers) are shown in Fig. 1 (B). No primary clarifier was designed for TH1 and TH2. Two internal recycles are designed in these plants. The first one is from aerobic zone to anoxic zone. The second one is for the return activated sludge (RAS) which was recycled from the 2 nd clarifier back to the anaerobic zone.

All wastewater samples from these four full-scale WWTPs were collected from each sampling points (anaerobic, anoxic, and aerobic zones) twice (between 2018 and 2019).

\section{Wastewater quality analysis}

All influent and effluent wastewater samples were analyzed for BOD, COD, $\mathrm{NH}_{4}{ }^{+}-\mathrm{N}, \mathrm{NO}_{2}{ }^{-}{ }^{-} \mathrm{N}, \mathrm{NO}_{3}{ }^{-}-\mathrm{N}$, organic- $\mathrm{N}, \mathrm{TKN}, \mathrm{TN}, \mathrm{TP}, \mathrm{TSS}$, and SS following the Standard Method [11]. Selective effluent samples were measured for E. coli.

\section{Microbiological analysis}

Molecular analysis of microbes was conducted for selected sludge samples from anaerobic, anoxic, and aerobic zones. Before DNA extraction step, the sludge of each tank was harvested and kept on ice. One $\mathrm{mL}$ of sludge was used for DNA extraction according to the procedures of Zhou et al. [12].

\section{Polymerase chain reaction (qPCR)}

Using quantitative polymerase chain reaction (qPCR) analysis focused to the microbial abundance. A 20- $\mu \mathrm{L}$ sample was mixed with $1 \mu \mathrm{L}$ of template DNA and 20 pmol of each primer. All qPCR reactions were performed by using a CFX96 Touch ${ }^{\text {TM }}$ Real-Time PCR and CFX Manager version 3.1.1517.0823. (Bio Rad Laboratories, Inc). An efficiency, slope and $r^{2}$ values of individual real-time PCR assays are $98.3-106.1 \%,(-3.1)-(-3.4), 0.993-0.997$ and linearity range is $10^{1}-10^{8}$, see Table S1. Oligonucleotide primers for PCR amplification via qPCR are shown in Table S2.

\section{Denaturing gradient gel electrophoresis (DGGE)}

Using denaturing gradient gel electrophoresis (DGGE) analysis focused to the microbial communities responsible for $\mathrm{N}$ removal. Total bacteria were identified via 16S-rRNA EUB gene. Ammonium-oxidizing bacteria and archaeal were identified through AOB-and AOA-amoA genes. Nitrite-oxidizing bacteria (NOB) were identified Nitrospira and Nitrobactervia 16S rRNA NSR and Nitro genes, respectively. Denitrifying bacteria (DNB) were identified via nirS, nirK and nosZ genes. Oligonucleotide primers for DGGE are shown in Table S3. Each $25-\mu \mathrm{L}$ reaction mixture was added with $1 \mu \mathrm{L}^{-1}$ of template DNA with concentration of $10-20$ $\mathrm{ng} \mu \mathrm{L}^{-1}$, 10X Ex Taq ${ }^{\mathrm{TM}}$ buffer, 5 units/ $\mu \mathrm{L}$ TaKaRa Ex Taq ${ }^{\mathrm{TM}}, 2.5 \mathrm{mM}$ dNTP Mixture, and 10 pmol of each primer, and the mixture was finally diluted with nuclease-free water. All PCR reactions were performed by using a T100 ${ }^{\mathrm{m}}$ Thermal cycler (BioRad Laboratories, CA and USA). (Bio Rad Laboratories, Inc.). The PCR product of $15 \mu \mathrm{L}$ was loaded into individual lanes on $8 \%(\mathrm{~W} / \mathrm{V})$ acrylamide gel with $35-55 \%$ gradient for EUB target and with $35-50 \%$ gradient for AOB target. And electrophoresis step was performed in $1 \mathrm{x}$ TAE buffer at $58{ }^{\circ} \mathrm{C}$ with a constant voltage at $80 \mathrm{~V}$ for $16 \mathrm{~h}$. The shaped DNA band on acrylamide gel was excised by a scalpel. The DNA fragments were eluted by milli-Q water and set aside in a refrigerator for overnight, and then amplified PCR with the same primer without attached CG-camp. Sequencing bases were aligned by using database of the National Center for Biotechnology Information (NCBI).

\section{Loading rate and removal rate calculation}

The removal efficiencies (\%) of nutrients and contaminants were calculated as Eq. (1).

$$
\text { Removal efficiency }(\mid \%)=\frac{\mathrm{C}_{\text {inf }}-\mathrm{C}_{\text {out }}}{\mathrm{C}_{\mathrm{inf}}} \times 100(1)
$$

where $\mathrm{C}_{\text {inf }}$ and $\mathrm{C}_{\text {out }}$ are concentrations $\left(\mathrm{mg} \mathrm{L}^{-1}\right)$ of water quality parameters in influent and effluent of a treatment process, respectively.

COD loading rate $\left(\mathrm{kg} \mathrm{COD} \cdot\left(\mathrm{m}^{3} \cdot \mathrm{d}\right)^{-1}\right)$, BOD loading rate $\left(\mathrm{kg} \mathrm{BOD} \cdot\left(\mathrm{m}^{3} \cdot \mathrm{d}\right)^{-1}\right)$, and Ammonia loading rate $($ ALR $)\left(\mathrm{kg} \mathrm{NH}{ }_{4}^{+}-\mathrm{N} \cdot\left(\mathrm{m}^{3} \cdot \mathrm{d}\right){ }^{-1}\right)$ were calculated according to the Eqs. (2), (3) and (4), respectively.

$$
\begin{aligned}
& \operatorname{COD}\left(\mathrm{kg}-\mathrm{N} / \mathrm{m}^{3} \cdot \mathrm{d}\right)=\frac{\mathrm{COD}_{\text {inf }} \times \mathrm{Q}}{\mathrm{V}}(2) \\
& \operatorname{BOD}\left(\mathrm{kg}-\mathrm{N} / \mathrm{m}^{3} \cdot \mathrm{d}\right)=\frac{\mathrm{BOD}_{\text {inf }} \times \mathrm{Q}}{\mathrm{V}}(3) \\
& \operatorname{ALR}\left(\mathrm{kg}-\mathrm{N} / \mathrm{m}^{3} \cdot \mathrm{d}\right)=\frac{\mathrm{NH}_{4}^{+} \text {inf } \times \mathrm{Q}}{\mathrm{V}}(4)
\end{aligned}
$$

where $\mathrm{COD}_{\text {inf }}$ and $\mathrm{BOD}_{\text {inf }}$ are concentration $\left(\mathrm{mg} \mathrm{L}^{-1}\right)$ of $\mathrm{COD}$ concentration of influent, $\left(\mathrm{kg}\right.$ COD $\left.\cdot\left(\mathrm{m}^{3}\right)^{-1}\right)$ and BOD concentration of influent, $\left(\mathrm{kg} \mathrm{BOD} \cdot\left(\mathrm{m}^{3}\right){ }^{-1}\right)$, respectively. $\mathrm{NH}_{4}{ }^{+}$inf is ammonia concentration of influent, $\left(\mathrm{kg} \mathrm{NH}_{4}{ }^{+}-\mathrm{N} \cdot\left(\mathrm{m}^{3}\right)^{-1}\right), \mathrm{Q}$ is flow rate, $\left(\mathrm{m}^{3} \cdot \mathrm{d}^{-1}\right)$, and $\mathrm{V}$ is volume of reactor, $\left(\mathrm{m}^{3}\right)$.

Free ammonia (FA) was calculated by Eq. (5) according to Anthonisen et al. [13]. 


$$
\mathrm{FA}(\mathrm{mg}-\mathrm{N} / \mathrm{L})=\frac{17}{14} \times \frac{\left[\mathrm{NH}_{4}^{+}\right]_{\mathrm{inf}} \times 10^{\mathrm{pH}}}{\exp \left[\frac{6334}{273+\mathrm{T}}+10^{\mathrm{pH}}\right]}
$$

where $\mathrm{NH}_{4}{ }^{+}$inf is ammonium concentration of influent $\left(\mathrm{mg}-\mathrm{N} \mathrm{L}^{-1}\right)$ and $\mathrm{T}$ is the temperature of effluent $\left({ }^{\circ} \mathrm{C}\right)$.

\section{Statistical analysis for microbial abundances}

Two-way multivariate analysis of variance (two-way MANOVA): Tukey's honestly significant difference (HSD, at $p<0.05)$ was performed using Minitab 18.1 for microorganism abundance as copies-DNA. The level of statistical significance and correlations were considered to be statistically significant with the $95 \%$.

\section{Results And Discussion}

\section{Major operational parameters of full-scale $\mathrm{A}^{2} \mathrm{O}$ processes}

Operational parameters of $\mathrm{A}^{2} \mathrm{O}$ processes in the four WWTPs are presented in Table 1. The $\mathrm{A}^{2} \mathrm{O}$ processes at TH1 were operated at the average flow rate of $218,433 \mathrm{~m}^{3} \mathrm{~d}^{-1}$. The average flow rate was 7,673 $\mathrm{m}^{3} \mathrm{~d}^{-1}$ for TH2. The average flow rates at SK1 and SK2 WWTPs were 220,655 and 497,174 $\mathrm{m}^{3} \mathrm{~d}^{-1}$, respectively. Flow rates from high to low are SK2 > SK2 TH1 > TH1. Compared with TH1 $\left(30 \mathrm{mg} \mathrm{L}^{-1}\right)$, TH2 $\left(198 \mathrm{mg} \mathrm{L}^{-1}\right)$, and SK1 (75 mg L $\left.\mathrm{T}^{-1}\right)$, high BOD values ( $260 \mathrm{mg} \mathrm{L}^{-1}$ ) were found at SK2 because the WWTP received industrial wastewaters as well (approximately $25 \%$ of total volume). TH1 received wastewater with very low BOD. It is because that TH1 treated wastewater collected from a combined sewer system with domestic sewage being diluted by stormwater. Infiltration and inflow are able to enter this combined sewer system. Meanwhile, the high temperature inside the sewer lines could promote the degradation of BOD. Finally, the wide practice of septic tanks installation in the residential houses could remove BOD before wastewater entering the sewer lines.

All operational parameters of DO, SRT, and HRT can be found in Table 1. Comparison these operational parameters at TH1, TH2, SK 1, and SK2, low DO level

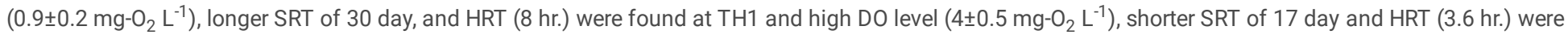

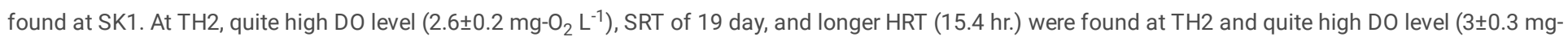
$\left.\mathrm{O}_{2} \mathrm{~L}^{-1}\right)$, quite longer SRT of 26 day, and longer HRT (10.1 hr.) were found at SK2. Longer SRT of $\geq 26$ day with DO level $\left(\geq 0.9 \pm 0.2 \mathrm{mg}-\mathrm{O}_{2} \mathrm{~L}^{-1}\right)$ could be suggested to use as operation parameters when treating low COD/N ratio wastewaters at TH1 or COD/N ratio of 4.2 at SK2.

\section{Performances of full-scale $A^{2} O$ processes WWTPs}

COD, BOD, and nitrogen removals efficiencies in the full-scale $\mathrm{A}^{2} \mathrm{O}$ processes WWTPs are shown in Table 2. COD, BOD, NH ${ }_{4}^{+}-\mathrm{N}, \mathrm{TN}$, and TP removals efficiencies were $67 \%, 83 \%, 95 \%, 49 \%$, and $35 \%$ respectively, at TH1. These values were $98 \%, 92 \%, 91 \%, 86 \%$, and $96 \%$ respectively, at TH 2 . They were $96 \%$, $89 \%, 99 \%, 70 \%$, and $95 \%$ respectively, at SK1, and were $99 \%, 96 \%, 98 \%, 82 \%$, and $98 \%$ respectively, at SK2.

The average nitrogen concentration and removal efficiencies in each month are shown in Figure 2. $\mathrm{A}^{2} \mathrm{O}$ processes are designed for biological $\mathrm{N}$ and $\mathrm{P}$ removals and suitable for municipal WWTP [1]. However, total nitrogen (TN) removal efficiency at TH1 was quite low (only 49\%) compared to other plants. The low TN removal performance could be explained by the very low COD/TN ratio (3.7) in the wastewater received at TH1. The low nitrogen removal efficiencies were also reported by Liu et al. [14] for WWTPs treating wastewater of relatively low COD/TN ratios. It was reported that denitrification process could not significantly occur due to the insufficient carbon source for denitrification process with wastewater having relatively low COD/TN ratios of lower than 4 . On the contrary, efficient TN removal (86\%) was reported for TH2 which received wastewater with COD/TN ratio of 8.4.

For WWTPs treating low COD/TN ratio $(\leq 4)$ wastewater, maintaining longer SRT ( $\geq 60$ day) is recommended to overcome the low TN removal efficiency [4] as the longer SRT would increase nitrifying bacteria abundancy. Meanwhile, long SRT could also enhance $\mathrm{NH}_{4}{ }^{+}$removal by increasing nitrification activity [1]. The effects of SRT on $\mathrm{NH}_{4}{ }^{+}$removal were reported by [5]. The effluent $\mathrm{NH}_{4}{ }^{+}$concentrations in activated sludge process were reported for SRTs at 5 day $\left(2.6 \pm 2.3 \mathrm{mg} \mathrm{N} \mathrm{L}^{-1}\right), 10$ day $\left(0.04 \pm 0.01 \mathrm{mg} \mathrm{N} \mathrm{L}^{-1}\right), 20$ day $\left(0.03 \pm 0.007 \mathrm{mg} \mathrm{N} \mathrm{L}^{-1}\right)$, and 40 day $\left(0.02 \pm 0.003 \mathrm{mg} \mathrm{N} \mathrm{L}^{-1}\right)$, corresponding to $\mathrm{NH}_{4}{ }^{+} \mathrm{N}$ removal efficiencies of $94.5 \%, 99.9 \%, 99.9 \%$, and $99.9 \%$, respectively. The effluent $\mathrm{NH}_{4}{ }^{+}$concentration at $\mathrm{TH}_{2}$ plant was $4.8 \mathrm{mg} \mathrm{N} \mathrm{L}{ }^{-1}$ and was the highest among the WWTPs studied due to the highest $\mathrm{NH}_{4}^{+}$concentration in the raw water $\left(55.4 \mathrm{mg} \mathrm{N} \mathrm{L}^{-1}\right)$. To further enhance the removal of $\mathrm{NH}_{4}^{+}-\mathrm{N}$, a long SRT of $>19$ day should be recommended.

The results of TP removal confirm that the $\mathrm{A}^{2} \mathrm{O}$ processes at three WWTPs (BOD/TP ratio of $>20$ ) was able to remove $\mathrm{P}$ concentration well (more than $96 \%$ of TP removal efficiencies) except TH1 which has lowest BOD/TP ratio of 13 and achieved only $35 \%$ of TP removal. To increase phosphorus removal efficiency at TH1 (in case there is low BOD:TP ratio), the chemical treatment by using alum as coagulant would be recommended.

Nitrogen-cycling microbial abundances and predominated existing would be relative with various environmental factors such as dissolved oxygen level, SRT, temperature, $\mathrm{pH}$, ammonium loading rates (ALRs), etc., and will be discussed in the following section.

\section{Nitrogen-cycling microbial abundances and communities}

Abundances and communities of ammonia-oxidizing bacteria (AOB) and ammonia-oxidizing archaeal (AOA) 
Autotrophic nitrifying bacteria responsible for ammonia oxidation process are detected at WWTP TH1 and belonged to two orders: Nitrosomonadales (affiliated to Nitrosomonas sp. Nitrosospira sp., Nitrosococcus sp., and Thiobacillus sp.) and Rhodocyclales (affiliated to Azospira sp., Thauera sp., and Zoogloea sp.) as shown in Table 3. Zhang et al. [15] reported that in full-scale municipal WWTPs, the most important genera of AOB were Nitrosomonas and Nitrosospira. Furthermore, they mentioned that Nitrosomonas were the most dominated ones. Consistently, in the full-scale $\mathrm{A}^{2} \mathrm{O}$ WWTPs, Nitrosomonas sp. are the most dominant AOB, especially in the WWTPs TH2, SK1, and SK2 which were operated at high DO levels. By contrast, the microbial community of Nitrosospira sp. was found at the TH1 because this WWTP was operated under long SRT, a favor condition for the growth of Nitrosospira sp. (see Table 3). Although the abundance of Nitrosospira sp. is less than that of Nitrosomonas sp., the existence of Nitrosospira sp. might be suitable a factor for satisfying good nitrification process when the conditions are not optimal for growth of nitrifying bacteria [16].

Figure $3 \mathrm{~A}$ shows the abundance of AOA-amoA genes at WWTP TH1, which is the highest among the WWTPs full-scale $\mathrm{A}^{2} \mathrm{O}$ process investigated, and the significance of each tank at TH1 shown the high mean difference of letter grouping in blue clustered column, $(p<0.05)$, see Table S4. The lower DO level, high temperature, and longer SRT (> 30 day) operated in this plant would significantly promote the growth of AOA [17]. Gao et al. [6] studied the effects of DO levels on the growth of $\mathrm{AOB}-\mathrm{amoA}$ and $\mathrm{AOA}-\mathrm{amoA}$, showing the former is much more abundance under high $\mathrm{DO}$ levels of $1.9-3.5 \mathrm{mg}-\mathrm{O}_{2} \mathrm{~L}^{-1}$. Phanwilai et al. [4] analyzed the abundance of microorganisms in the step-feed aerobic tanks of a municipal wastewater treatment plant, reporting that $A O A-a m o A$ was the most abundance genes in the tank with low $\mathrm{DO}$ levels $\left(0.9 \pm 0.5 \mathrm{mg}-\mathrm{O}_{2} \mathrm{~L}^{-1}\right)$ while AOB-amoA gene was higher than AOA-amoA genes in the tank with high $\mathrm{DO}$ level $\left(1.8 \pm 0.5 \mathrm{mg}_{-} \mathrm{O}_{2} \mathrm{~L}^{-1}\right)$. In this work, the result of AOB and AOA abundance at WWTPs TH2, SK1, and SK2, which are operated at high DO levels of 2.6$4 \mathrm{mg}-\mathrm{O}_{2} \mathrm{~L}^{-1}$, is inline with the results by Gao et al. [6] and Phanwilai et al. [4] (see Figure 3A). Other factors such as the high $\mathrm{NH}_{4}{ }^{+}$loading rate could also increase AOB abundance. The predominated AOB-amoA gene over AOA-amoA gene at TH2, SK1, and SK2 compared to TH1 could be attributed to the higher $\mathrm{NH}_{4}{ }^{+}$loading rates in these plants (see Table 2), and the significance of the gene $(p<0.05)$ shown difference of letter grouping in orange clustered bar chart (see Table S4). The typical design DO level for a nitrogen-removal process of around $2 \mathrm{mg}-\mathrm{O}_{2} \mathrm{~L}^{-1}$ was recommended by [1].

Although abundance of AOA was not found three WWTPS TH2, SK2, and SK3, AOA and AOB would collaborate and offer possible advantage in ammonia oxidation rates at lower ammonia concentration at TH1. It is postulated that in the practical operation, it is desire to maintain low DO level in an aerobic tank to reduce energy and sustaining SRT range base on characteristics of each full-scale WWTP, the abundance of AOA might be possible group of microorganisms to collaborate with AOB for nitrification process. However, in further research on suitable DO level and SRT range would be investigated to find the optimum conditions of growth AOA that could collaborate with AOB.

\section{Abundances and communities of nitrite-oxidizing bacteria (NOB)}

Figure 3B shows that Nitrobacter sp. was more abundance than Nitrospira sp. at WWTP TH1. The DO levels $\left(0.7\right.$ to $\left.1.1 \mathrm{mg}^{-\mathrm{O}_{2}} \mathrm{~L}^{-1}\right)$ at TH1 are the lowest among the WWTPs investigated (DO concentration from 2.4 to $4.5 \mathrm{mg}^{-} \mathrm{O}_{2} \mathrm{~L}^{-1}$ for the other three WWTPs), and the temperature range at TH1 is moderate high at $27.7-28.1^{\circ} \mathrm{C}$. The low DO condition is favorable for the growth of Nitrobacter. Huang et al. [7] reported that DO concentration of $>1.0 \mathrm{mg}-\mathrm{O}_{2} \mathrm{~L}^{-1}$ was suitable condition for the growth of Nitrobacter while DO concentration of $<1.0 \mathrm{mg}-\mathrm{O}_{2} \mathrm{~L}^{-1}$ was optimum condition of Nitrospira. Similarly, Park et al. [18] suggested that at the low operational DO concentration of $0.5-0.6 \mathrm{mg}-\mathrm{O}_{2} \mathrm{~L}^{-1}$, Nitrospira was selectively enriched over Nitrobacter in the activated sludge from a small-scale SBR. Furthermore, Liu and Wang [19] investigated the nitrification performance of activated sludge with the long-term effect of low DO concentration, finding that higher abundance of Nitrospira $\left(10^{12}\right)$ than abundance of Nitrobacter $\left(10^{10.4}\right)$ under the condition of $0.16 \mathrm{mg}-\mathrm{O}_{2} \mathrm{~L}^{-1}$.

The optimal temperature ranges for Nitrobacter and Nitrospira growth are still ambiguous. Huang et al. [7] concluded that Nitrobacter was favorable species under the temperature ranges of $24-25^{\circ} \mathrm{C}$ while Nitrospira dominated at relatively high temperature range of $29-30^{\circ} \mathrm{C}$. On the contrary, Alawi et al. [20] indicated that lower temperature range of $10-20^{\circ} \mathrm{C}$ was the optimum condition for Nitrospira growth. Roots et al. [21] mentioned that Nitrospira

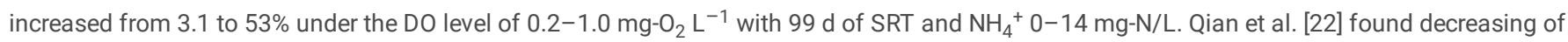
Nitrospira from $0.44 \%$ to $0.04 \%$ by DO level of $0.8-1.5{\mathrm{mg}-\mathrm{O}_{2}}^{\mathrm{L}^{-1}}$ with SRTs between 33 and $56 \mathrm{~d}$ and $\mathrm{NH}_{4}^{+} 105 \mathrm{mg}-\mathrm{N} / \mathrm{L}$. While Sun et al. [23] set a short SRT of $15 \mathrm{~d}$ with DO concentration at 1.0 and $2.0 \mathrm{mg}^{-} \mathrm{O}_{2} \mathrm{~L}^{-1}$ that increased 1.81 and $2.99 \%$, respectively. Under the longer SRT (30 d) with the DO level (0.7$1.1 \mathrm{mg}-\mathrm{O}_{2} \mathrm{~L}^{-1}$ ) at TH1 presented low abundance of Nitrospira than Nitrobacter, while the three plants with the shorter SRT (17 to $26 \mathrm{~d}$ ) and higher DO level of $2.4-4.5 \mathrm{mg}-\mathrm{O}_{2} \mathrm{~L}^{-1}$ presented high abundance of Nitrobacter than Nitrospira. However, the point of SRT could not be one major effect on Nitrospira but other factors: DO, temperature, ammonium influent, $\mathrm{pH}, \mathrm{HRT}$, FA. ALR could also be the significant factors affecting the competition between Nitrospira and Nitrobacter[9].

At WWTPs TH2, SK1, and SK2, Nitrospira was more abundance than Nitrobacter. These plants were operated at relatively DO of 2.6 to 4 mg- ${ }_{2} \mathrm{~L}^{-1}$, HRT of 3.6 to $15.4 \mathrm{hr}$., and SRT of 17 to $26 \mathrm{~d}$. These operation parameters along with ammonium loading rate $\left(A L R, \mathrm{NH}_{4}{ }^{+}-\mathrm{N} / \mathrm{m}^{3}\right.$-d) were important factors affecting Nitrospira growth but less extent on Nitrobacter growth.

Meanwhile, Nitrobacter is more sensitive to the free ammonia (FA) concentration compared to Nitrospira [10]. Mehrani et al. [9] reported that FA was a major

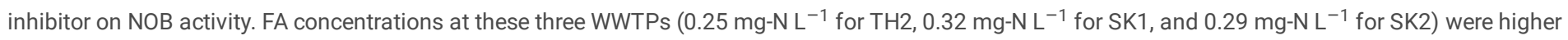
than that at TH1 $\left(0.17 \mathrm{mg}-\mathrm{N} \mathrm{L}^{-1}\right)$. It could be postulated that FA concentration was inhibitor to decrease abundance of Nitrobacter in these three WWTPs.

In this work, only qPCR technique was used to identify both Nitrobacter and Nitrosipra. The specific primers to detect nitrifying bacteria population via the DGGE technique were not used. As Nitrosipra are able to complete oxidation of $\mathrm{NH}_{4}{ }^{+}$direct to $\mathrm{NO}_{3}{ }^{-}$without into $\mathrm{NO}_{2}{ }^{-}$(complete ammonia oxidizer, comammox 
process), the specific primers to detect nitrifying bacteria population for Nitrobacter and Nitrosipra are recommended in the further research. In practical, if the information of Nitrosipra in full-scale WWTP is reliable, a new approach of comammox process would be applied for increasing BNR in the future.

\section{Abundances and communities of denitrifying bacteria (DNB)}

Three coding genes of nitrite (nirK or nirS) and nitrous oxide (nosZ) reductases were evaluated for the abundance of denitrifying bacteria from these four fullscale WWTPs. As indicated in Figure 3C, higher abundance of nosZ-type denitrifiers was found at TH1 among WWTPs investigated due to the low COD/TN ratio of $\leq 3.7$ in TH1 (see Table S4). The effects of COD/TN ratio on the abundance of nosZ-type denitrifiers were consistent with the results reported by Yuan et al. [24] who reported that the nosZ-type denitrifiers was two orders of magnitude more at the influent COD/TN ratio of $4.6\left(1.29 \times 10^{8}\right.$ copies) compared to that at COD/TN ratio of $8.4\left(1.31 \times 10^{6}\right.$ copies $)$ at the Beijing municipal WWTP in China.

The average number of DNB copy presenting at TH1 shows that nosZ-type denitrifiers in anoxic and anaerobic tanks were most dominated. Wang et al. [25] found that the abundance of nos $Z$ was a good indicator for rechecking anoxic and anaerobic conditions, having more oxygen concentration those conditions. Base on this result, it can be concluded that the DO level in the anoxic and anaerobic tanks of TH1 were quite high, and denitrifying bacteria could not use $\mathrm{NO}_{3}{ }^{-}$electron acceptor for denitrification process, resulting in poor denitrification efficiency at TH1 in anoxic condition. As shown in Table 2, DO level in anoxic tank at $\mathrm{TH} 1$ was $0.3 \pm 0.1 \mathrm{mg}-\mathrm{O}_{2} \mathrm{~L}^{-1}$. It should be noted that the low denitrification efficiency at $\mathrm{TH} 1$ could also attributed to the low COD/TN ratio in the receiving water.

Tallec et al. [26] and Jia et al. [27] indicated that low DO concentration in WWTPs favors nitrous oxide $\left(\mathrm{N}_{2} \mathrm{O}\right)$ production during nitrification/denitrification process. High abundance of nos $Z$ gene in denitrifies was also found in aerobic tank of WWTP TH1. Henry et al. [28] indicated that nosZ-type denitrifiers could be responsible in $\mathrm{N}_{2} \mathrm{O}$ production. It could be postulated that the BNR process at TH1 could produce higher $\mathrm{N}_{2} \mathrm{O}$ gas among WWTPs investigated due to the low DO level of this plant $\left(0.9 \pm 0.2 \mathrm{mg}-\mathrm{O}_{2} \mathrm{~L}^{-1}\right)$.

On the other hand, the high abundance of nirStype denitrifiers and less abundance of nosZ-type denitrifiers were found in anaerobic and anoxic tanks at TH2, SK1, and SK2 due to high DO centration (2.6-4.5 mg- $\mathrm{O}_{2} \mathrm{~L}^{-1}$ ) operated at the $\mathrm{A}^{2} \mathrm{O}$ process. Meanwhile, nirS-type denitrifiers were higher than the nirK-type denitrifiers at all full-scale WWTPs. Complete denitrification is possible with nirS-type denitrifiers [25]. Che et al. [29] found a predominance of nirS-type level over nirK-type of all eight full-scale municipal WWTPs in different cities of China. Based regression analysis, Zhang et al. [30] suggested that the abundance of nirk-type denitrifiers was correlated with temperature and nirS-type denitrifiers was linearly correlated with temperature and ammonium concentration.

Both heterotrophic and autotrophic communities of denitrifying bacteria were found as indicated in Table 3. Heterotrophic denitrifying bacteria (Ilumatobacter sp., Comamonas sp., Rhodoferax sp., Terrimonas sp., Niabella sp., Sediminibacterium sp., Tistrella sp., Oryzobacter sp.) are normally found in WWTPs [31, 32] Autotrophic denitrifying bacteria belonging to Arcobacter (affiliated Arcobacter suis) relate to pathogenic bacteria that were found in high abundance in the municipal full-scale biological $\mathrm{N}$ and $\mathrm{P}$ removals processes [33]. Kristensen et al. [34] reported that pathogenic Arcobacter bacteria was not found in WWTPs with longer SRT (25-35 day) because they could be able to pass through both anoxic and aerobic tanks. In this work, Arcobacter suis was only found at SK1. Other filamentous autotrophic denitrifying bacteria were commonly found in wastewater worldwide and were presented. Chloroflexi plays a role in sludge flocculation and is more commonly found in WWTPs designed to remove nutrients, and most appearance with a long SRT operation and expose the biomass to anaerobic conditions [35]. Haliscomenobacter sp. were filamentous bacteria and satisfied being in phosphorus concentrations [36]. Their filamentous bacteria were found and achieved to remove phosphorus in $\mathrm{A}^{2} \mathrm{O}$ processes.

\section{Conclusions}

High nitrogen removal performances of full-scale $\mathrm{A}^{2} \mathrm{O}$ process (TH2 and SK2 that high COD/TN ratios were 8.4 and 5.6, respectively) are successful with operation parameters, such as DO level ( $\geq 2.6 \mathrm{mg}^{-} \mathrm{O}_{2} \mathrm{~L}^{-1}$ ) and SRT (19-26 day). However, to improve nitrogen removal efficiency at WWTPs TH1 (COD/TN ratio of $\leq 3.7)$ and SK1 (COD/TN ratio of $\leq 4.2)$ would be possible if longer SRT (> 30 day) is operated. The result from this work is confirm that the $A^{2} O$ processes are be able to remove $\mathrm{P}$ concentration well in case there are BOD/TP ratios of $\geq 19$.

Low DO level $\left(0.9 \pm 0.2 \mathrm{mg}^{-} \mathrm{O}_{2} \mathrm{~L}^{-1}\right)$ and long SRT under low COD/TN ratio $(\leq 3.7)$ at $\mathrm{TH} 1$ is responsible for the high abundances of AOA over AOB. Nitrosospira could be an appearance at the long SRT maintaining. In contrary, high COD/TN ratio (>4.2) contributed the abundance of AOB over AOA. The predominated Nitrosomonas were the most existence and others AOB population as Azospira, Nitrosococcus, Thiobacillu, Thauera, and Zoogloea were found.

The nirS outnumbered nirk-type denitrifiers. Nitrospira sp. are more competitive than Nitrobacter sp. at the low operational DO concentration. However, abundance of Nitrobacter could be higher than abundance of Nitrospira under lower temperature conditions. Chloroflexi and Haliscomenobacter representative for the autotrophic denitrifying bacterium and Ilumatobacter, Comamonas, Rhodoferax, Terrimonas, Niabella, Sediminibacterium, Tistrella, and Oryzobacter species played on the heterotrophic denitrifying bacteria. In case of high abundance of gene-type denitrifiers (nosZ) could be found in both anaerobic and anoxic tanks. It could be indicated that there were quite high DO concentrations in both tanks. Maintaining low DO level as operation condition in WWTP full-scale $\mathrm{A}^{2} \mathrm{O}$ process for saving energy, it could be postulated to produce high amount of $\mathrm{N}_{2} \mathrm{O}$ gas rather than operating high DO level. The future research in this area should be recommended in full-scale WWTP.

\section{Declarations}

\section{Availability of data and materials}


The data used to support the findings of this study are available from the corresponding author upon request.

\section{Competing interests}

The authors declare they have no competing interests.

\section{Funding}

This is research has received funding support from the NSRF via the Program Management Unit for Human Resources and Institutional Development, Research and Innovation (grant number: B16F630088) and the Postdoctoral Fellowship from Kasetsart University.

\section{Authors' contributions}

All authors read and approved the final manuscript.

Supaporn Phanwilai: Performing research, analyzing data, and writing on the first draft

Pongsak (Lek) Noophan: Initiative idea of project including funding acquisition, designing research, troubleshooting, analyzing data, and writing- review and editing

Chi-Wang Li: Writing - review and editing

Kwang-Ho Choo: Writing - review and editing

\section{Acknowledgements}

This research work was supported by the NSRF via the Program Management Unit for Human Resources and Institutional Development, Research and Innovation (grant number: B16F630088) and Postdoctoral Fellowship from Kasetsart University Research and Development Institute (KURDI). The authors also would like to thank for great supporting from Faculty of Engineering, Kasetsart University and Miss Nimaradee Boonapatcharoen at Pilot Plant Development and Training Institute King Mongkut's University of Technology Thonburi (Bangkuntien) for giving helpful suggestions on molecular techniques.

\section{References}

1. Tchobanoglous G, Burton FL, Stensel HD. Wastewater Engineering: Treatment and Reuse. 4th ed. Singapore: McGraw-Hill Higher Education. 2004.

2. Qian G, Li L, Hu X, Yu X, Ye L. Enhancement of the biodegradability of activated sludge by the electric-coagulation multistage A/O membrane bioreactor treating low C/N industrial wastewater. Int Biodeterior Biodegrad. 2017;125:1-12.

3. Huang X, Dong W, Wang H, Jiang S. Biological nutrient removal and molecular biological characteristics in an anaerobic-multistage anaerobic/oxic (AMAO) process to treat municipal wastewater. Bioresour Technol. 2017;241:969-78.

4. Phanwilai S, Noophan P, Li C-W, Choo K-H. Effect of COD:N ratio on biological nitrogen removal using full-scale step-feed in municipal wastewater treatment plants. Sustain Environ Res. 2020;30(1):1-9.

5. Liu G, Wang J. Role of solids retention time in ammonia-based feedback aeration control. J Environ Eng. 2016;142(7):1-8.

6. Gao JF, Luo X, Wu GX, Li T, Peng YZ. Quantitative analyses of the composition and abundance of ammonia-oxidizing archaea and ammonia-oxidizing bacteria in eight full-scale biological wastewater treatment plants. Bioresour Technol. 2013;138:285-96.

7. Huang Z, Gedalanga PB, Asvapathanagul P, Olson BH. Influence of physicochemical and operational parameters on Nitrobacter and Nitrospira communities in an aerobic activated sludge bioreactor. Water Res. 2010;44:4351-58.

8. Chen C, Ouyang W, Huang S, Peng X. Microbial community composition in a simultaneous nitrification and denitrification bioreactor for domestic wastewater treatment. IOP Conf Ser: Earth Environ Sci. 2018;112:012007.

9. Mehrani MJ, Sobotka D, Kowal P, Ciesielski S, Makinia J. The occurrence and role of Nitrospira in nitrogen removal systems. Bioresour Technol. 2020;303:122936.

10. Ushiki N, Jinno M, Fujitani H, Suenaga T, Terada A, Tsuneda S. Nitrite oxidation kinetics of two Nitrospira strains: The quest for competition and ecological niche differentiation. J. Biosci Bioeng. 2017;123(5):581-9.

11. APHA. Standard methods for the examination of water and wastewater, $23^{\text {rd }}$ ed. Washington, DC: American Public Health Association; 2005.

12. Zhou L, Bruns MA, Tiedje JM. DNA recovery from soils of diverse composition. Appl Environ Microbiol. 1996;62(2):316-22.

13. Anthonisen AC, Loehr C, Prakasam TBS, Srinath EG. Inhibition of nitrification and nitrous acid compounds. J Water Pollut. Control Fed. 1976;48:835-52.

14. Liu HB, Yang CZ, Pu WH. Removal of nitrogen from wastewater for reusing to boiler feed-water by an anaerobic/aerobic/membrane bioreactor. Chem Eng J. 2008;140:122-29.

15. Zhang T, Ye L, Yan Tong AH, Shao M-F, Lok S. Ammonia-oxidizing archaea and ammonia-oxidizing bacteria in six full-scale wastewater treatment bioreactors. Appl Microbiol Biotechnol. 2011;91:1215-25.

16. Siripong S, Rittmann BE. Diversity study of nitrifying bacteria in full-scale municipal wastewater treatment plants. Water Res. 2007;41:1110-20.

17. Yin Z, Bi X, Xu C. Ammonia-oxidizing archaea (AOA) play with ammonia-oxidizing bacteria (AOB) in nitrogen removal from wastewater. Archaea. 2018;4:8429145. 
18. Park MR, Park H, Chandran K. Molecular and kinetic characterization of planktonic Nitrospira spp. selectively enriched from activated sludge. Environ Sci Technol. 2017;51:2720-28.

19. Liu G, Wang J. Long-term low DO enriches and shifts nitrifier community in activated sludge. Environ Sci Technol. 2013;47:5109-117.

20. Alawi M, Lipski A, Sanders T, Eva Maria P, Spieck E. Cultivation of a novel cold-adapted nitrite oxidizing betaproteobacterium from the Siberian Arctic. Isme J. 2007;1:256-64.

21. Roots P, Wang Y, Rosenthal A, Griffin J, Sabba F, Petrovich M, Yang F, Kozak J, Zhang H, Wells G. Comammox Nitrospira are the dominant ammonia oxidizers in a mainstream low dissolved oxygen nitrification reactor. Water Res. 2018;157:396-405.

22. Qian F, Wang J, Shen Y, Wang Y, Wang S, Chen X. Achieving high performance completely autotrophic nitrogen removal in a continuous granular sludge reactor. Biochem Eng J. 2017;118:97-104.

23. Sun Z, Liu C, Cao Z, Chen W. Study on regeneration effect and mechanism of high-frequency ultrasound on biological activated carbon. Ultrason Sonochem. 2018;44:86-96.

24. Yuan Q, Wang HY, Chua Z-S, Hang Q-Y, Liu K, Li CM. Influence of C/N ratio on MBBR denitrification for advanced nitrogen removal of wastewater treatment plant effluent. Desalin Water Treat. 2017;66:158-65.

25. Wang Z, Zhang XX, Lu X. Liu B, Li Y, Long C, Li A. Abundance and diversity of bacterial nitrifiers and denitrifiers and their functional genes in tannery wastewater treatment plants revealed by high-throughput sequencing. PLoS One. 2014;9(11):e113603.

26. Tallec G, Garnier J, Billen G, Gousailles M. Nitrous oxide emissions from secondary activated sludge in nitrifying conditions of urban wastewater treatment plants: effect of oxygenation level. Water Res. 2006;40:2972-80.

27. Jia W, Liang S, Zhang J, Ngo HH, Guo W, Yan Y, Zou Y. Nitrous oxide emission in low-oxygen simultaneous nitrification and denitrification process: sources and mechanisms. Bioresour Technol. 2013;136:444-51.

28. Henry S, Bru D, Stres B, Hallet S, Philippot L. Quantitative detection of the nosZ gene, encoding nitrous oxide reductase, and comparison of the abundances of 16S rRNA, narG, nirK, and nosZ genes in soils. Appl Environ Microbiol. 2006;72(8):5181-89.

29. Che Y, Liang P, Gong T, Cao X, Zhao Y, Yang C, Song C. Elucidation of major contributors involved in nitrogen removal and transcription level of nitrogen cycling genes in activated sludge from WWTPs. Scientific Reports, 2017;7:44728.

30. Zhang L, Zeng G, Zhang J, Chen Y, Yu M, Lu L. Li H, Zhu Y, Yuan Y, Huang A, He L. Response of denitrifying genes coding for nitrite (nirK or nirS) and nitrous oxide (nosZ) reductases to different physico-chemical parameters during agricultural waste composting. Appl Microbiol Biotechnol. 2015;99:4059-70.

31. Heylen K, Vanparys B, Wittebolle L, Verstraete W, Boon N, Vos PD. Cultivation of denitrifying bacteria: Optimization of isolation conditions and cultivation of denitrifying bacteria diversity study. Appl Environ Microbiol 2006;72(4):2637.

32. Mcllroy SJ, Starnawska A, Starnawski P, Saunders AM, Nierychlo M, Nielsen PH, Nielsen JL. Identification of active denitrifiers in full-scale nutrient removal wastewater treatment systems. Environ Microbiol. 2016;18(1):50-64.

33. Lu X, Zhang XX, Wang Z, Huang K, Wang Y, Liang W, Tan Y, Liu B, Tang J. Bacterial pathogens and community composition in advanced sewage treatment systems revealed by metagenomics analysis based on high-throughput sequencing. PLoS One. 2015;10:1-15.

34. Kristensen JM, Nierychlo M, Albertsen A, Nielsena PH. Bacteria from the genus Arcobacter Are abundant in effluent from wastewater treatment plants. Appl Environ Microbiol. 2020;86(9):03044-19.

35. Speirs LBM, Rice DTF, Petrovski S, Seviour RJ. The phylogeny, biodiversity, and ecology of the Chloroflexi in activated sludge. Front Microbiol. 2019;10:128.

36. Kämpfer P, Weltin D, Hoffmeister D, Dott W. Growth requirements of filamentous bacteria isolated from bulking and scumming sludge. Water Res. 1995;29: 1585-88.

\section{Tables}

Table 1 Operational parameters of the full-scale A20 processes 


\begin{tabular}{|lllll|}
\hline Parameter & \multicolumn{4}{l}{ anaerobic, anoxic, and aerobic processes } \\
\cline { 2 - 5 } & Thailand & \multicolumn{3}{l|}{ Korea } \\
\cline { 2 - 5 } & TH1 & TH2 & SK1 & SK2 \\
\hline Avg. Flow rate $\left(\mathrm{m}^{3} \mathrm{~d}^{-1}\right)$ & 218,433 & 7,673 & 220,655 & 497,174 \\
\hline SRT (day) & 30 & 19 & 17 & 26 \\
\hline HRT (total) (hour) & 8 & 15.4 & 3.6 & 10.1 \\
Anaerobic & 0.5 & 1.3 & 1.0 & 1.3 \\
\hline Anoxic & 1.5 & 3.1 & 1.6 & 2.6 \\
\hline Aerobic & 6 & 11 & 1.0 & 6.2 \\
\hline DO (mg- ${ }_{2} \mathrm{~L}^{-1}$ ) & $0.3 \pm 0.1$ & 0.1 & Negligible & Negligible \\
Anoxic & & & & \\
\hline Aerobic & $0.9 \pm 0.2$ & $2.6 \pm 0.2$ & $4 \pm 0.5$ & $3 \pm 0.3$ \\
\hline
\end{tabular}

Table 2 The average physical and chemical characteristics of influent and effluent in full-scale $A^{2} O$ processes 


\begin{tabular}{|c|c|c|c|c|c|}
\hline \multirow[t]{3}{*}{ Parameters } & & \multicolumn{4}{|c|}{ Anaerobic, anoxic, and aerobic $\left(\mathrm{A}^{2} \mathrm{O}\right)$ processes } \\
\hline & & \multicolumn{2}{|c|}{ Thailand } & \multicolumn{2}{|c|}{ South Korea } \\
\hline & & TH1 & $\mathrm{TH} 2$ & SK1 & SK2 \\
\hline \multirow[t]{2}{*}{$\mathrm{pH}$} & Inf. & 7.2 & 6.8 & 7.2 & 7.1 \\
\hline & Eff. & 7.2 & 6.9 & 6.9 & 6.8 \\
\hline \multirow[t]{2}{*}{ Temp $\left({ }^{\circ} \mathrm{C}\right)$} & Inf. & 28.1 & 27 & $14-29$ & $11-23$ \\
\hline & Eff. & 27.7 & 27 & $18-30$ & $19-26$ \\
\hline \multirow[t]{3}{*}{$\mathrm{SS}\left(\mathrm{mg} \mathrm{L}^{-1}\right)$} & Inf. & 46.7 & 178.5 & 202 & 407 \\
\hline & Eff. & 8.6 & 4.68 & 2 & 1.0 \\
\hline & $\%$ & 82 & 97 & 99 & 100 \\
\hline \multirow[t]{3}{*}{$\mathrm{BOD}\left(\mathrm{mg} \mathrm{L}^{-1}\right)$} & Inf. & 30.1 & 197.9 & 75 & 260 \\
\hline & Eff. & 5.0 & 3.1 & 3 & 1 \\
\hline & $\%$ & 83 & 98 & 96 & 99 \\
\hline \multirow[t]{3}{*}{$\operatorname{COD}\left(\mathrm{mg} \mathrm{L}^{-1}\right)$} & Inf. & 58 & 512 & 88 & 155 \\
\hline & Eff. & 19 & 40.5 & 10 & 6 \\
\hline & $\%$ & 67 & 92 & 89 & 96 \\
\hline \multirow[t]{3}{*}{$\mathrm{NH}_{4}^{+}\left(\mathrm{mg}-\mathrm{N} \mathrm{L}^{-1}\right)$} & Inf. & 11.0 & 55.4 & 10.6 & 4.3 \\
\hline & Eff. & 0.6 & 4.8 & 0.1 & 0.1 \\
\hline & $\%$ & 95 & 91 & 99 & 98 \\
\hline \multirow[t]{2}{*}{$\mathrm{NO}_{3}^{-}\left(\mathrm{mg}-\mathrm{N} \mathrm{L}^{-1}\right)$} & Inf. & 0.2 & NR & 0.1 & 0.1 \\
\hline & Eff. & 5.3 & NR & 6.3 & 5.8 \\
\hline \multirow[t]{2}{*}{ Alkalinity $\left(\mathrm{mg} \mathrm{L}^{-1}\right)$} & Inf. & NR & 344.2 & NR & NR \\
\hline & Eff. & NR & 154.3 & NR & NR \\
\hline \multirow[t]{3}{*}{$\operatorname{TKN}\left(\mathrm{mg} \mathrm{L}^{-1}\right)$} & Inf. & 15.4 & 60.8 & NR & NR \\
\hline & Eff. & 2.6 & 6.1 & NR & NR \\
\hline & $\%$ & 83 & 90 & - & - \\
\hline \multirow[t]{3}{*}{$\mathrm{TN}\left(\mathrm{mg} \mathrm{N} \mathrm{L}{ }^{-1}\right)$} & Inf. & 15.6 & 61.2 & 27 & 49 \\
\hline & Eff. & 8.0 & 8.9 & 8 & 9 \\
\hline & $\%$ & 49 & 86 & 70 & 82 \\
\hline \multirow[t]{3}{*}{$\mathrm{TP}\left(\mathrm{mg} \mathrm{P} \mathrm{L}{ }^{-1}\right)$} & Inf. & 2.3 & 7.1 & 4 & 10 \\
\hline & Eff. & 1.5 & 0.3 & 0.2 & 0.2 \\
\hline & $\%$ & 35 & 96 & 95 & 98 \\
\hline \multirow[t]{2}{*}{ E. Coli (MPN) } & Inf. & NR & NR & 44,845 & 163,369 \\
\hline & Eff. & NR & NR & 22 & 118 \\
\hline \multicolumn{2}{|l|}{$\mathrm{COD} / \mathrm{TN}$ ratio } & 3.7 & 8.4 & 4.2 & 5.6 \\
\hline \multicolumn{2}{|l|}{ BOD/TP ratio } & 13 & 28 & 19 & 26 \\
\hline \multicolumn{2}{|c|}{ COD loading rate $\left(\mathrm{kg}-\mathrm{COD} \cdot\left(\mathrm{m}^{3} \mathrm{~d}\right)^{-1}\right)$} & 2.83 & 9.44 & 2.11 & 2.86 \\
\hline \multicolumn{2}{|c|}{ BOD loading rate $\left(\mathrm{kg}-\mathrm{BOD} \cdot\left(\mathrm{m}^{3} \mathrm{~d}\right)^{-1}\right)$} & 1.44 & 3.65 & 1.80 & 4.80 \\
\hline \multicolumn{2}{|c|}{$\operatorname{ALR}\left(\mathrm{kg} \mathrm{NH}_{4}{ }^{+}-\mathrm{N} \cdot\left(\mathrm{m}^{3} \mathrm{~d}\right)^{-1}\right)$} & 0.53 & 1.02 & 0.25 & 0.08 \\
\hline \multicolumn{2}{|l|}{$\mathrm{FA}\left(\mathrm{mg}-\mathrm{N} \mathrm{L}^{-1}\right)$} & 0.17 & 0.25 & 0.32 & 0.29 \\
\hline
\end{tabular}

Remark: NR $=$ Not record and $\%=\%$ Removal efficiency 
Table 3 Microorganisms' community in four municipal WWTPs of $A^{2} O$ processes

Page $11 / 15$ 


\begin{tabular}{|c|c|c|c|c|c|c|c|c|c|c|c|c|c|c|c|}
\hline \multirow[t]{3}{*}{ Sample name } & & \multirow[t]{3}{*}{$\%$} & \multirow{3}{*}{$\begin{array}{l}\text { Accession } \\
\text { No. }\end{array}$} & \multicolumn{6}{|c|}{$\mathrm{A}^{2} / 0$ processes } & \multicolumn{6}{|c|}{$\mathrm{A}^{2} / 0$ processes } \\
\hline & & & & \multicolumn{3}{|l|}{ TH1 } & \multicolumn{3}{|l|}{$\mathrm{TH} 2$} & \multicolumn{3}{|l|}{ SK1 } & \multicolumn{3}{|l|}{ SK2 } \\
\hline & & & & Ana & Anx & Aer & Ana & Anx & Aer & Ana & Anx & Aer & Ana & Anx & Aer \\
\hline \multicolumn{16}{|l|}{ Nitrifying bacteria } \\
\hline \multicolumn{16}{|c|}{ Ammonia oxidizing bacteria (AOB) } \\
\hline Order & Species & & & & & & & & & & & & & & \\
\hline \multirow[t]{10}{*}{ Nitrosomonadales } & Nitrosomonas aestuarii & 90 & NR104818.1 & + & + & + & & & & & & & & & \\
\hline & $\begin{array}{l}\text { Nitrosomonas } \\
\text { eutropha }\end{array}$ & 93 & NR027566.1 & + & + & + & & & & + & + & + & + & + & + \\
\hline & $\begin{array}{l}\text { Nitrosomonas } \\
\text { communis }\end{array}$ & 97 & NR119314.1 & + & + & + & + & + & + & + & + & + & + & + & + \\
\hline & $\begin{array}{l}\text { Nitrosomonas } \\
\text { halophila }\end{array}$ & 93 & NR104817.1 & + & + & + & & & & + & + & + & & & \\
\hline & $\begin{array}{l}\text { Nitrosomonas } \\
\text { oligotropha }\end{array}$ & 96 & NR104820.1 & + & + & + & + & + & + & & & & & & \\
\hline & Nitrosomonas ureae & 97 & NR104814.1 & + & + & + & + & + & + & & & & & & \\
\hline & $\begin{array}{l}\text { Nitrosospira } \\
\text { multiformis }\end{array}$ & 96 & NR074736.1 & + & + & + & & & & & & & & & \\
\hline & Nitrosospira tenuis & 97 & NR114773.1 & + & + & + & & & & & & & & & \\
\hline & $\begin{array}{l}\text { Uncultured } \\
\text { Nitrosospira }\end{array}$ & 95 & GQ255611.1 & + & + & + & & & & & & & & & \\
\hline & Thiobacillus thioparus & 96 & NR117864.1 & + & + & + & + & + & + & & & & & & \\
\hline Rhodocyclales & Zoogloea caeni & 91 & NR043795.1 & & & & + & + & + & & & & & & \\
\hline
\end{tabular}

Nitrite oxidizing bacteria (NOB)

$\begin{array}{lllll}\text { Nitrospirae } & \text { Nitrospira lenta } & 99 & \text { NR148573.1 } & +\end{array}++$

\section{Denitrifying bacteria (DNB)}

Autotrophic denitrifying bacteria

\begin{tabular}{|c|c|c|c|c|c|c|c|c|c|c|c|c|c|c|c|}
\hline Campylobacterales & Arcobacter suis & 81 & NR116729.1 & & & & & & & & & & + & + & + \\
\hline \multirow[t]{2}{*}{ Chloroflexi } & Chloroflexi bacterium & 87 & KP246879.1 & & & & & & & & & & & & \\
\hline & Uncultured Chloroflexi & 98 & GQ366686.1 & & & & & & & + & + & + & + & + & + \\
\hline \multirow[t]{3}{*}{ Rhodocyclales } & Azospira restricta & 97 & NR044023.1 & + & + & + & & & & & & & & & \\
\hline & Thauera aromatica & 100 & NR026153.1 & + & + & + & & & & & & & & & \\
\hline & $\begin{array}{l}\text { Thauera } \\
\text { aminoaromatica }\end{array}$ & 93 & NR027211.1 & & & & & & & & & & & & \\
\hline Saprospirales & $\begin{array}{l}\text { Haliscomenobacter } \\
\text { hydrossis }\end{array}$ & 90 & NR074420.1 & + & + & + & + & + & + & + & + & + & + & + & + \\
\hline
\end{tabular}

Heterotrophic denitrifying bacteria

\begin{tabular}{|c|c|c|c|c|c|c|c|c|c|c|c|c|}
\hline Acidimicrobiales & Ilumatobacter fluminis & 86 & NR041633.1 & & & & + & + & + & + & + & + \\
\hline \multirow[t]{3}{*}{ Burkholderiales } & $\begin{array}{l}\text { Comamonas } \\
\text { denitrificans }\end{array}$ & 99 & NR025080.1 & & & & & & & & & \\
\hline & $\begin{array}{l}\text { Comamonas } \\
\text { phosphati }\end{array}$ & 96 & NR147778.1 & & & & & & & & & \\
\hline & $\begin{array}{l}\text { Rhodoferax } \\
\text { ferrireducens }\end{array}$ & 92 & NR074760.1 & + & + & + & + & + & + & + & + & + \\
\hline \multirow[t]{2}{*}{ Chitinophagales } & Terrimonas lutea & 96 & NR041250.1 & + & + & + & + & + & + & + & + & + \\
\hline & Niabella terrae & 92 & NR132698.1 & & + & + & & & & & & \\
\hline
\end{tabular}




\begin{tabular}{|c|c|c|c|c|c|c|c|c|c|c|c|c|c|c|c|}
\hline & $\begin{array}{l}\text { Sediminibacterium } \\
\text { roseum }\end{array}$ & 82 & NR159130.1 & & & & & & & + & + & + & + & + & + \\
\hline Rhodospirillales & Tistrella mobilis & 91 & NR117256.1 & + & + & + & & & & & & & & & \\
\hline Micrococcales & Oryzobacter terrae & 98 & NR137270.1 & + & + & + & + & + & + & + & + & + & + & + & + \\
\hline
\end{tabular}

Remark: + is DGGE band presenting on acrylamide gel, Ana is an anaerobic tank, Anx is an anoxic tank, and Aer is an aerobic tank.

\section{Figures}

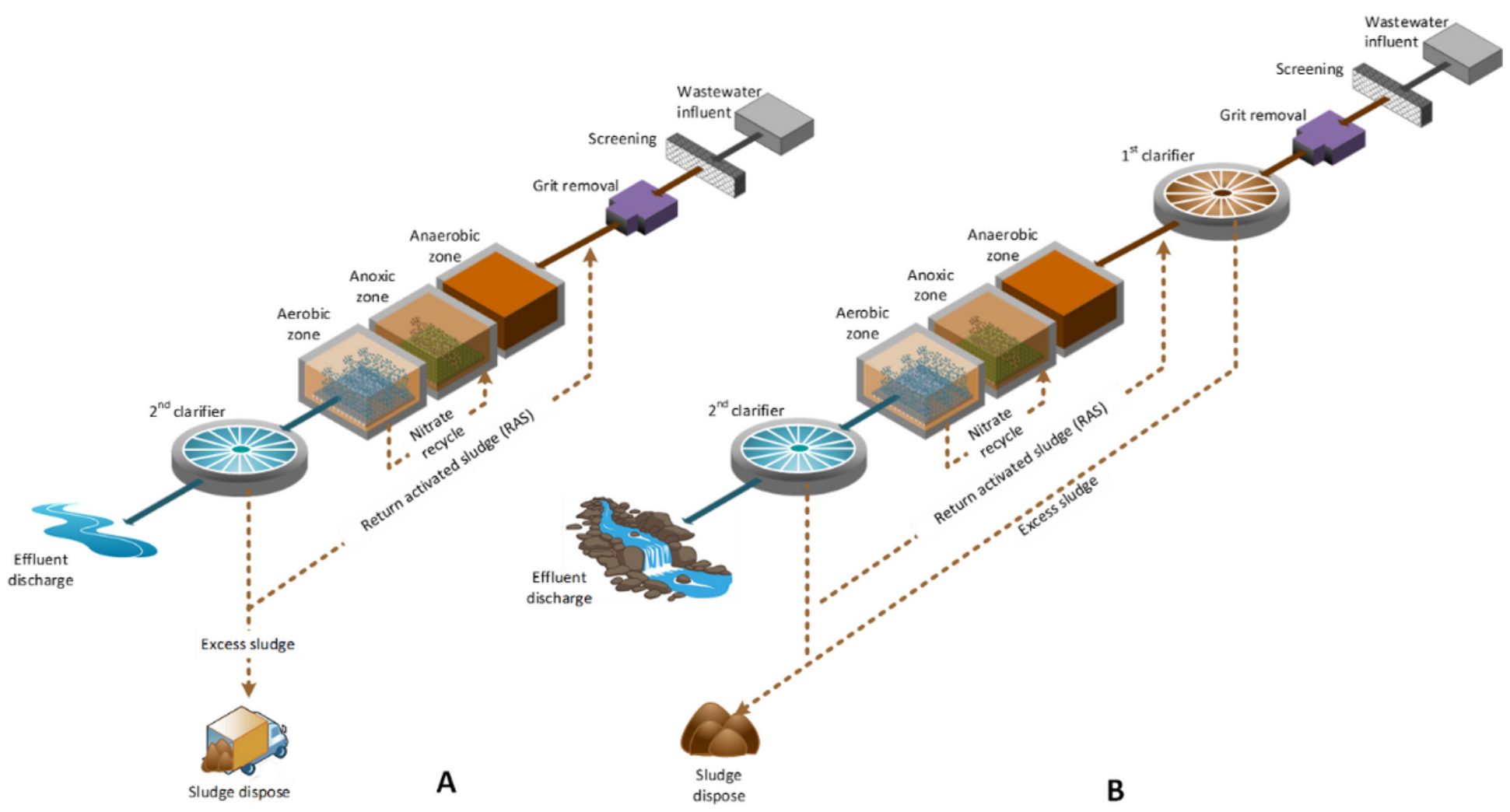

\section{Figure 1}

The schematic layout of the full-scale WWTPs at TH1 and TH2 WWTPs (A), and SK1 and SK2 WWTPs (B) 

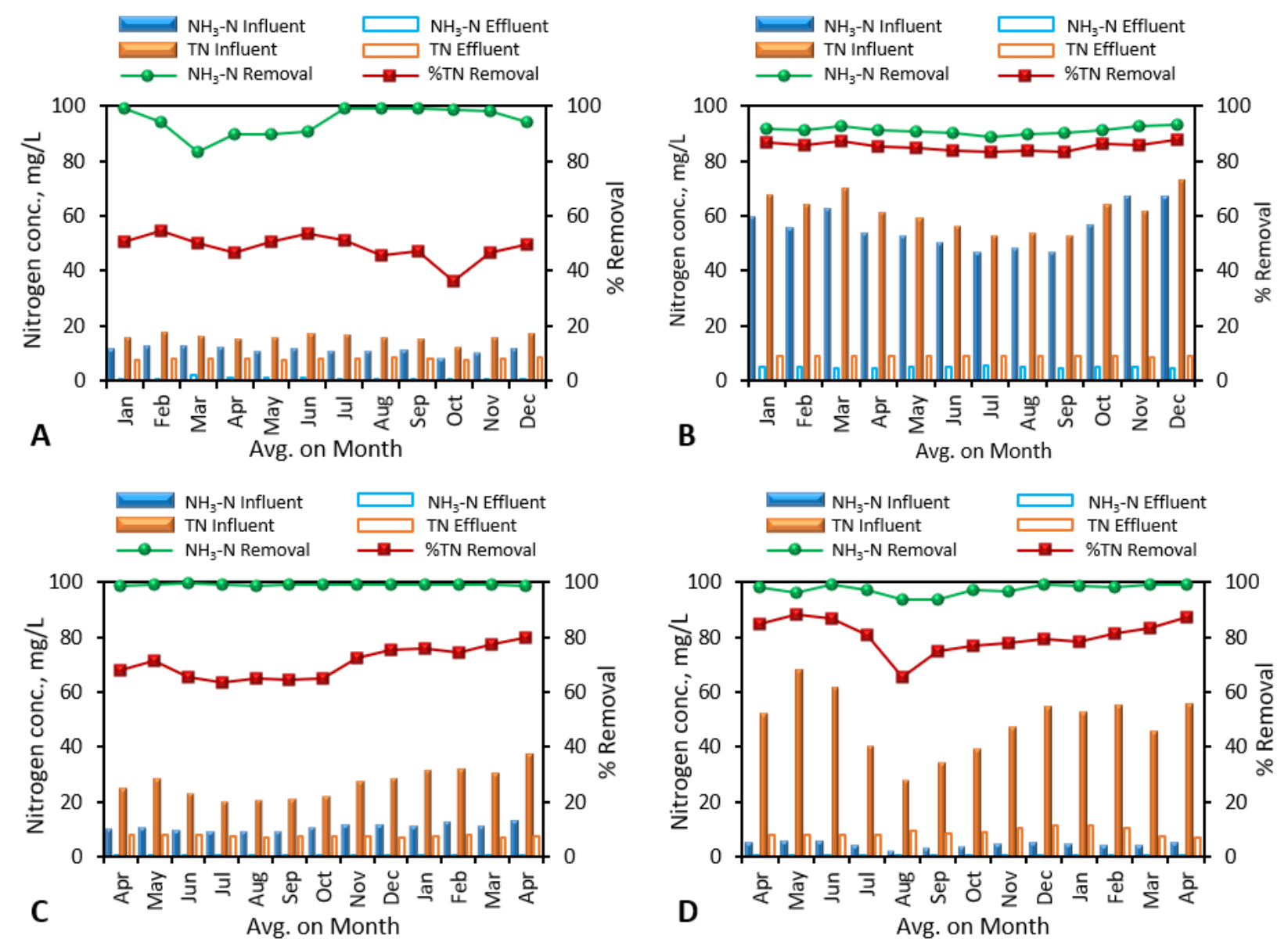

Figure 2

Nitrogen performance A2O processes at (A) TH1, (B) TH2, (C) SK1 and (D) SK2 

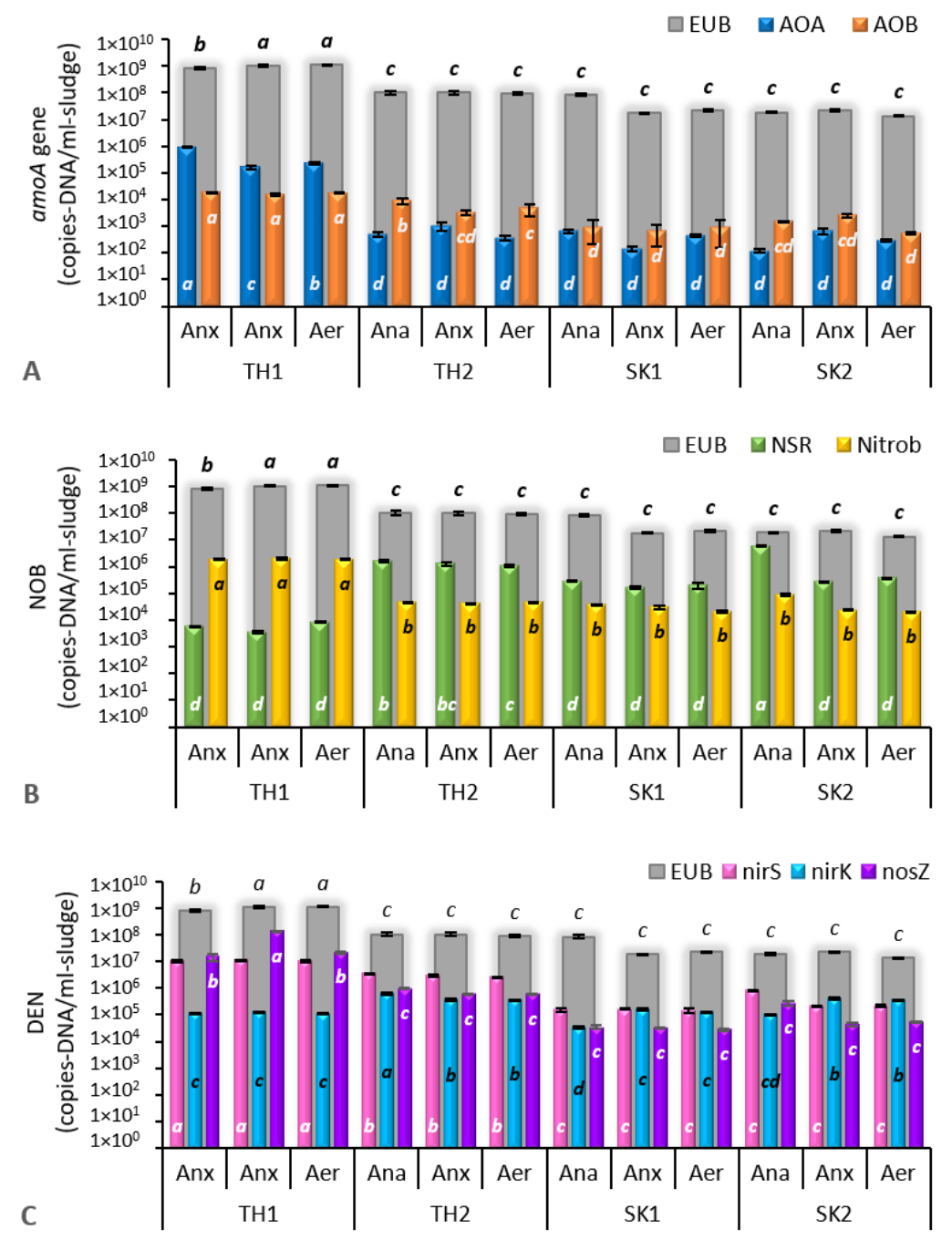

Figure 3

Microbial abundance of (A) AOA and AOB (B) NOB and (C) DEN target at TH1, TH2, SK1, and SK2

\section{Supplementary Files}

This is a list of supplementary files associated with this preprint. Click to download.

- A2OManuscriptSupplementaryMaterials.docx 